\title{
Brand Awareness and Quality Product on Purchase Decision Mediating Consumer Perception: Case Study in PT. Tugu Pratama Indonesia
}

\author{
Iwan Kurniawan Subagja*, Nur Alamsyah, Eddy Sanusi Silitonga, Harry Indratjahyo \\ Universitas Krisnadwipayana, PO BOX 7774 / Jat Cm Jakarta, 13077, Indonesia
}

\section{*Corresponding Author}

Iwan Kurniawan Subagja

\section{Article History}

Received: 24.09.2019

Accepted: 02.10 .2019

Published: 30.10 .2019

\begin{abstract}
This study aimed to analyze the influence of brand awareness and product quality on purchasing decisions through consumer perception. The research was conducted at PT Tugu Pratama Indonesia by the number of samples are 119 people in the area of the organization. Sampling using a saturated sample. Analysis of data using path analysis. The results showed that influence brand awareness and product quality on purchasing decisions by consumers' perceptions of positive and significant influence.
\end{abstract}

Keywords: Brand awareness, product quality, consumer perceptions, purchasing decisions.

\section{INTRODUCTION}

Decision-making is of significant importance for the reciprocation of an organization, especially for the future of an organization is determined by the current decision making. The importance of decision-making in terms of the power to make a decision as to whether to follow the pattern of centralization or decentralization. Decision-making in addition to terms of power also in terms of presence, namely the absence of decision-making theory administration, we can not understand, did predict the actions of management so we can enhance management effectiveness.

Machfoedz [1] argues that decision-making is a process of assessment and selection of the various alternatives in accordance with particular interests by setting an option deemed most favorable. The assessment process usually begins with identifying key issues affecting the purpose, organizing, analyzing, and selecting the various alternatives and make decisions that are considered the best. The final step of the process is an evaluation system to determine the effectiveness of the decisions taken.

The more issues to be decided was felt to be at a tough level, then the search will be crucial information about the effectiveness of the decision. Conversely, if the matter was routine would occur repeatedly, that information only serves as a benchmark for knowledge on the matter was held. Or in other words, the amount of effort used in problem-solving tends to decline with the growing recognition of a product and the more inexperience person in making decisions.

Purchasing decisions are influenced brand awareness, product quality and consumer perceptions of insurance. brand awareness related to brand recall in the minds of consumers. Brand awareness is important for producers, because consumers will tend to buy products that are known or remembered by him, The higher level of brand awareness means a growing brand in mind or in the minds of consumers compared to other brands.

Furthermore, brand awareness rather is a memory only, but it is a learning process for the consumer to a brand. Building brand awareness is usually done in a long time, since memorization can succeed with repetition and reinforcement. In fact, the brands with a high level of a recall are brands that old age. Consumers will tend to buy products with a brand they are familiar with the product from those of the mark is still unfamiliar to them.

Another factor influencing the purchase decision is the quality of the product. The quality of products according to Kotler [2] is the ability of a product to show a variety of functions including durability, reliability, accuracy and ease of use. A product can be said to have good quality when the product is included in these dimensions. With the existence of these dimensions in a product, it is

Copyright @ 2019: This is an open-access article distributed under the terms of the Creative Commons Attribution license which permits unrestricted use, distribution, and reproduction in any medium for non commercial use (NonCommercial, or CC-BY-NC) provided the original author and source are credited. 
expected that the product has more value than competitors' products. Build quality of the products is a strategic step that must be taken by the company. This is due to that the quality of the product is a better value or superior value in the eyes of customers. Achievement of quality value achieved by building a better process and production systems that can suppress the relatively cheaper cost.

Improved product quality is very important, thus the company's products are increasingly high quality. If the product quality improvements implemented by the company, then the company will be able to remain satisfied customers and can increase the number of consumers. In the development of a company, product quality issues will also determine whether or not the rapid development of the company. If the situation becomes more intense marketing competition, the role of product quality will be even greater in the development of the company.

Consumer perceptions of insurance also affect the purchasing decision. Consumer perception is a process that makes a person choose, organize, and interpret the stimuli received into a meaningful and complete picture of the world.

\section{LITERATURE REVIEW Decision-Making}

Decision-making is the most important aspect of management activities. Decision-making is an everyday job in management so we need to know whether the decision was, how do we arrive at a decision, any decision, levels of classification, and the types. In addition, please also note the decision-making techniques, approaches methods, theories, ethics in decision-making, the role of bureaucracy in decision-making and the relationship between decision-making and problem-solving.

The decision means the choice, that choice of two or more possible. However, almost not a choice between right and wrong, but that it often occurs is the choice between the "almost true" and that "possibly wrong". Although used to say the same decision with the choice, there are important differences between the two. The decision was a "real choice" for selection interpreted as a selection of destinations including options on how to achieve that goal, whether at the individual level or at the collective level. Decision relation to the process of the final stage of a process that is more dynamic, labeled decision. The decision is seen as a process because it consists of a series of related activities and not only regarded as a prudent action.

Furthermore Amirullah [3] that: "The decision is a process of assessment and selection of the various alternatives in accordance with particular interests by setting an option deemed most favorable." The decision has important meaning for reciprocation of an organization, especially since the future of an organization is determined by the current decision making. The importance of decision-making in terms of the power to make a decision as to whether to follow the pattern of centralization or decentralization. Decision-making in addition to terms of power also in terms of presence, namely the absence of decision-making theory administration, we can not understand,

Machfoedz [1] argues that decision-making is a process of assessment and selection of the various alternatives in accordance with particular interests by setting an option deemed most favorable. The assessment process usually begins with identifying key issues affecting the purpose, organizing, analyzing, and selecting the various alternatives and make decisions that are considered the best. The final step of the process is an evaluation system to determine the effectiveness of the decisions taken.

According to Swastha and Handoko [4] argues that: "The decision to purchase is a process in the purchase of real, whether to buy or not." Based on the pattern of the relationship between the type of business (issues), the highest and most businesses are low, then we can distinguish three levels of consumer decision-making as proposed by Amirullah [1] as follows:

- Extensive problem-solving. At this level the consumer is in dire need much more convincing information for decisions to be taken. Consumers in this case have had special criteria for goods to be chosen. Decision making also involves decisions of extensive multi-choice and cognitive and behavioral efforts significantly. Finally, these decisions tend to require longer periods of time.

- $\quad$ Limited problem-solving. At this level the consumer does not so much need information, but consumers still have to look for more information to give faith. Usually, consumers who are at this level are always comparing with digging brand or goods kept information. Here fewer alternatives considered and similarly with the process of integration required. Selection decisions involving limited usually quite fast, with rates of cognitive and behavioral attempts being.

- Routinized response behavior. Because consumers have had much experience of buying, then the information is usually not necessary. The information sought is simply to compare the course, even though the decision was already thought of. Compared to another level, the behavior of the routine takes very little choice of cognitive capacity or conscious control. Basically, the plan has been studied consumer decisions reactivated from memory and carried out automatically to generate consumer behavior.

The factors that influence consumer behavior by Suryani [5] product purchases is as follows:

a. Product 
The tool marketing mix is the most basic products. Product is everything that can be offered by manufacturers to note, sought, bought, used, or consumed as fulfilling market needs or desires the relevant market. Products not meant in this case can be physical goods, services, personalities, places, organizations, and ideas.

b. Price

Prior to market their products in the market, companies need to set the price of the product. Price is one important element of marketing in today's world specialty trade in the world of competition for every company. Definition of prices by Gitosudarmo [6] "price is the amount of money needed to acquire some goods and certain services or a combination of both".

\section{c. Promotion}

Promotion is one important aspect of marketing activities, for promotion can influence consumer behavior, against the company's products. Besides, the promotion can be used as communication between manufacturers to the costumers. Promotion is also a means to introduce the type, price, shape, color and quality of the products produced.

d. Place

Employers should deploy the goods to the consumer where it is located. It is the task to distribute goods to consumers. For this purpose the entrepreneur can use different forms of distribution channels might do.

\section{Consumer Perception}

Consumer perception is a process that makes a person choose, organize, and interpret the stimuli received into a meaningful and complete picture of the world. From the definition, that a person is motivated to buy is influenced by his perceptions of the situation, whereas what is perceived someone may be quite different from objective reality. Individuals may look at the same thing but perceive or describe it differently. Consumer perception will make the process as follows:

1. The stimuli

The stimuli or stimulus is a form of physical, visual or verbal communication that may affect individuals. Stimuli consisted of 2 types:

Marketing stimuli: any communication or physical stimuli designed to influence consumers. Product and components (such as packaging, content, physical characteristics) are the main stimuli. Communication designed to influence consumers are additional stimuli that represent products such as words, images, and symbols or through other stimuli associated with a product such as a price, product sales took place, and the influence of access. Environmental stimuli: physical stimuli that are designed to affect the environment.

2. The process of perception.

Perception arises because of the stimulus from the outside that will affect a person through the five senses tools namely sight, hearing, smelling, feeling and touch. The stimulus will be selected, organized and interpreted by each person in their own way.

\section{Selection}

The process begins with the perception of stimuli of the senses is called a sensation. These stimuli vary considerably and will always bombard the senses of the consumer. When viewed from the origin, there are stimuli that come from the individual (such as aroma, advertising, etc.) and that comes from within the individual such expectations, needs and experiences.

According to Vandayuli [7] one of the success factors of relationship marketing is the trust factor of the parties involved in the relationship. At the moment one believes the other party in inter-personal relationships, he will hang himself on the other party and will further raise its intention to maintain relationships represented in the form of loyalty buy [8]. Morgan and Hunt [9] say that trust and commitment is the key intermediary in building loyalty [10]. Meanwhile research Ramadania [10] obtained results that trust is an essential part of the formation of commitment, and commitment have a tendency to fight preferences become a key pioneer for loyalty.

\section{Brand Awareness}

Brand awareness related to brand recall in the minds of consumers. Brand awareness is important for producers, because consumers will tend to buy products that are known or remembered by him, brand awareness has four levels, as follows:

- Unaware brand the lowest level in the pyramid brand, where consumers are not aware of the existence of a brand.

- Brand recognition is the minimum level of brand awareness where it is important when a buyer selects a brand when making a purchase.

- $\quad$ Brand recall is the recollection of the brand without passing assistance because unlike recognition task.

- Top of mind is the first brand in mind when consumers were asked about a product category that can be recalled spontaneously without assistance.

The higher level of brand awareness means a growing brand in mind or in the minds of consumers compared to other brands. Furthermore, brand awareness rather is a memory only, but it is a learning process for the consumer to a brand. Building 
brand awareness is usually done in a long time, since memorization can succeed with repetition and reinforcement. In fact, the brands with a high level of a recall are brands that old age. Consumers will tend to buy products with a brand they are familiar with the product from those of the mark is still unfamiliar to them.

\section{Product Quality}

Products are defined as anything that can be offered to the market to be considered, owned, used, or consumed so as to satisfy the desires or needs [2]. Consumers will prefer products that offer quality, performance, and innovation that is different from other products.

The quality of products according to Kotler [2] is the ability of a product to show a variety of functions including durability, reliability, accuracy and ease of use.

According to Tjiptono [11], to determine the dimensions of quality products, can through eight dimensions as follows:

- Performance, this is related to the functional aspect of an item and is considered the main characteristics of the customer in buying the goods.

- Features, namely the aspect of performance that is useful for adding basic functions, relating to the selection of products and development.

- Reliability, matters relating to the probability of an item successfully perform their functions whenever used in a certain time period and under certain conditions as well.

- Conformance, this is related to the level of conformity with the specifications set previously by the customer desires.

- Durability, which is a reflection of the economic life in the form of the size of the durability or lifetime of goods.

- Serviceability, the characteristics associated with speed, competence, convenience, and accuracy in providing services to repair the goods.

- Aesthetics, is a characteristic that is subjective about aesthetic values related to personal consideration and reflection of individual preferences.

- $\quad$ Perceived quality, consumers do not always have complete information about product attributes. However, the consumer usually has information on the products indirectly.

A product can be said to have good quality when the product is included in these dimensions. With the existence of these dimensions in a product, it is expected that the product has more value than competitors' products. Build quality of the products is a strategic step that must be taken by the company. This is due to that the quality of the product is a better value or superior value in the eyes of customers. Achievement of quality value achieved by building a better process and production systems that can suppress the relatively cheaper cost. Therefore, product quality is a competitive tool is effective in achieving competitive advantage.

According to Kotler and Armstrong [12] is the characteristic quality of the product in the ability to meet the needs that have been determined and latent. Meanwhile, according to Garvin and Timpe [13], is the quality of the advantages possessed by the product. Quality in view of the consumer is the thing that has its own different scope with quality in view of the current manufacturers put out a quality product that is commonly known as the fact.

According to Kotler [2], quality is defined as the overall characteristics and properties of the goods and services that affect the ability to meet the needs expressed or implied. Meanwhile, according to Tjiptono [11], the quality is the combination of characteristics which determine the extent to which output can meet the requirements of customer needs or assess how far the properties and characteristics that meet their needs.

Based on the definitions above, it can be concluded that the quality of a product and services through several stages of the process by calculating the value of a product and services without the slightest deficiency value of products and services, and products and services according to the high expectations of customers.

\section{Research Methods \\ Object of Research}

The study was conducted on an insurance consumer PT. Tugu Pratama Indonesia.

\section{Population and Sample Research}

The population is a generalization region consisting of the objects/subjects that have a certain quantity and characteristics defined by the researchers to learn and then drawn conclusions [14]. Samples were towing the majority of the population to represent the entire population [15].

The population used in this study is the number of customers the company is as many as 2,500 people. The number of samples taken by the formula Slovin ie $n=2500 /(1+2500 \times 0,12)=119$. This sampling method is simple random. 


\section{RESULTS AND DISCUSSION}

\section{Effect of Brand Awareness and Product Quality on Purchasing Decisions}

Based on the analysis using SPSS, note that the value $f$ calculated at 86.747 and significance of 0.00 . This value is less than 0.05 . This means that the variable brand awareness and product quality influence on purchase decisions simultaneously. The magnitude of the effect of the independent variable on the dependent variable can be seen from $r$ squared value of $59.9 \%$ meaning that the variable brand awareness and product quality influence on purchase decisions reached $59.9 \%$ while the rest influenced by other variables that are not incorporated into the model equations.

\section{Analysis of Effect of Brand Awareness on Purchase Decision}

Results of the analysis of the effect of brand awareness on purchasing decisions are partially known that brand awareness coefficient of 0.521 . T value of 6.604 . The significant value of 0.00 . The significance value smaller than 0.05 . This means that the brand awareness variable influence on purchase decisions partially. Brand awareness level of influence on purchase decisions known $r$ squared value of 0.272 . This translates into brand awareness variables influence on purchasing decisions by $27.2 \%$ and the rest influenced by other variables not included in the model equations.

\section{Impact Analysis Product Quality on Purchase Decision}

The analysis results of product quality on purchase decisions partially known that product quality coefficient of 0.633 . T value of 8.850 . The significant value of 0.00 . The significance value smaller than 0.05 . This means that the variable quality of products influences on purchase decisions partially. The amount of influence on purchase decisions of product quality note $r$ squared value of 0.401 . This means that the effect of variable quality products to the purchasing decision amounted to $40.1 \%$ and the rest influenced by other variables not included in the model equations.

\section{Analysis Influence of Consumer Perceptions on Purchase Decision}

The analysis results of consumer perceptions of the work to the purchasing decision are partially known that consumer perception coefficient of 0.860 . T value of 18.248. The significant value of 0.00 . The significance value smaller than 0.05 . This means that the variable perception influence consumer purchase decisions partially. The amount of influence consumer perceptions on purchase decisions known $r$ squared value of 0.740 . This means that the effect of variable consumer perceptions on purchasing decisions by $74.0 \%$ and the rest influenced by other variables not included in the model equations.

\section{Analysis of Effect of Brand Awareness and Product Quality on Purchase Decision through Consumer Perception}

It is known that the effect of brand awareness on purchasing decisions is 0.521 . Brand awareness influence on purchasing decisions by consumers' perceptions is $0.643 \times 0.860=0.553$. In this case the indirect effect is greater than the direct effect so that it can be said that consumer perception variable working as an intervening variable. It is known that directly influence the quality of products to the purchasing decision is 0.633 . While the influence of the quality of products on purchase decisions through consumer perception of work is $0.756 \times 0.860=0.650$. In this case smaller than the direct influence indirect influence so that it can be said that consumer perception variable as an intervening variable.

\section{CONCLUSIONS AND SUggestions CONCLUSION}

Variable brand awareness and product quality influence on purchase decisions simultaneously. $F$ value calculated at 86.747 and significance of 0.00 . This value is less than 0.05 . R squared value of $59.9 \%$ meaning that the variable brand awareness and product quality influence on purchase decisions reached $59.9 \%$ while the rest influenced by other variables that are not incorporated into the model equations.

Variable brand awareness influence on purchase decisions partially. T value of 6.604 . The significant value of 0.00 . The significance value smaller than 0.05 . $\mathrm{R}$ squared value of 0.272 . This translates into brand awareness variables influence on purchasing decisions by $27.2 \%$ and the rest influenced by other variables not included in the model equations.

Variable quality of products influence on purchase decisions partially. T value of 8.850 . The significant value of 0.00 . The significance value smaller than 0.05 . $R$ squared value of 0.401 . This means that the effect of variable quality products to the purchasing decision amounted to $40.1 \%$ and the rest influenced by other variables not included in the model equations.

Variable perceptions influence consumer purchase decisions partially. T value of 18.248. The significant value of 0.00 . The significance value smaller than 0.05 . R squared value of 0.740 . This means that the effect of variable consumer perceptions on purchasing decisions by $74.0 \%$ and the rest influenced by other variables not included in the model equations.

Brand awareness influence on purchasing decisions is 0.521 . Brand awareness influence on purchasing decisions by consumers' perceptions is $0.643 \times 0.860=0.553$. In this case the indirect effect is greater than the direct effect so that it can be said that consumer perception variable as an intervening variable. 
The direct effect of product quality to the purchasing decision is 0.633 . While product quality Influence on purchase decision through consumer perception of work is $0.756 \times 0.860=0.650$. In this case smaller than the direct influence indirect influence so that it can be said that consumer perception variable working as an intervening variable.

\section{SUGGESTION}

Purchasing decisions are influenced brand awareness, product quality and consumer perception. brand awareness can be improved by increasing brand recall in the minds of consumers. Brand awareness is important for producers, because consumers will tend to buy products that are known or remembered by him, The higher level of brand awareness means a growing brand in mind or in the minds of consumers compared to other brands.

Furthermore, brand awareness rather is a memory only, but it is a learning process for the consumer to a brand. Building brand awareness is usually done in a long time, since memorization can succeed with repetition and reinforcement. In fact, the brands with a high level of a recall are brands that old age. Consumers will tend to buy products with a brand they are familiar with the product from those of the mark is still unfamiliar to them. Memory manufacturer of the product increased by increasing the frequency of advertisements in various media.

\section{REFERENCES}

1. Machfoedz, M. (2005). Pengantar Pemasaran Modern, edisi pertama, cetakan pertama, Penerbit: UPP AMP YKPN, Yogyakarta.

2. Kotler, P. (2007). Manajemen Pemasaran. Edisi Kesebelas Jilid Dua. Jakarta: Indeks.

3. Amirullah. (2002). Perilaku Konsumen. Graha Ilmu: Yogyakarta.

4. Swastha, B., \& Handoko, T. H. (2008). Manajemen Pemasaran, Analisa Perilaku Konsumen, edisi pertama, cetakan keempat, Penerbit: BPFE, Yogyakarta.

5. Suryani, T. (2008). Perilaku konsumen: implikasi pada strategi pemasaran. Yogyakarta: Graha IImu, 118.

6. Gitosudarmo, I. (2008), Manajemen Pemasaran, edisi pertama, cetakan keempat, Penerbit: BPFE - Yogyakarta.

7. Vandayuli. (2003). Quality Performance dan Komitmen Organisasi Jurnal Media Riset bisnis dan Manajemen, 4(3).

8. Dharmmesta, B. S., \& Darsono, L. I. (2005). Kontribusi involvement dan trust in a brand dalam membangun loyalitas pelanggan. Jurnal Ekonomi dan Bisnis Indonesia, 20(3).

9. Morgan, R. M., \& Hunt, S. D. (1994). The commitment-trust theory of relationship marketing. Journal of marketing, 58(3), 20-38.

10. Ramadania. (2002). Kepercayaan dan Komitmen Sebagai Perantara Kunci Relationship Marketing Dalam Membangun Loyalitas. Jurnal Riset Ekonomi dan Manajemen, 2(1), 33-52.

11. Tjiptono, F., Chandra, G., \& Adriana, D. (2008). Pemasaran strategik. Yogyakarta: Andi.

12. Kotler dan Amstrong. (2008). Prinsip-prinsip Pemasaran. Jilid 1 dan 2. Edisi 12. Jakarta: Erlangga.

13. Garvin, D., \& Timpe, A. D. (2005). Seri Ilmu dan Seni Manajemen Bisnis "Kinerja". Jakarta: Gramedia Asri Media.

14. Sugiyono. (2013). Metode Penelitian Manajemen. Bandung: Alfabeta.

15. Surakhmad, W. (2010). Pengantar Penelitian IImiah Dasar Metode Teknik. Bandung: Tarsito. 